Public Abstract

First Name:atanu

Middle Name:

Last Name:sen

Adviser's First Name:Dr.Shubhra

Adviser's Last Name:Gangopadhyay

Co-Adviser's First Name:Dr.Kevin

Co-Adviser's Last Name:Gillis

Graduation Term:SS 2008

Department:Biological Engineering

Degree:MS

\title{
Title:QUANTIFICATION OF CELL ATTACHMENT ON DIFFERENT MATERIALS AS CANDIDATE ELECTRODES FOR MEASUREMENT OF QUANTAL EXOCYTOSIS
}

A high throughput BioMEMS or lab-on-a-chip device is being developed for single cell capture for the purpose of high time resolution quantal exocytosis measurement with high probability of cell docking. This device makes use of DLC (Diamond like Carbon) deposited on a conducting ITO (Indium Tin Oxide) film to bring about a suitable electrode incorporating biocompatibility, transparency and low resistivity and electrochemical activity to enhance cell docking and detect catecholamine release.Various materials have been tested for their ability to promote cell attachment. Diamond-like Carbon being an established biocompatible and cytophilic material has been compared with other metal electrodes for cell attachment using an assay developed for this study. Cells tested for attachment were either the insulin-secreting cell line INS-1 or catecholamine-secreting bovine chromaffin cells. With either cell type, I found that the rank order of cell attachment following overnight culture was DLC > ITO, Pt $>\mathrm{Au}$. Teflon has also tested as a candidate insulating material to prevent cell attachment outside of this docking site. The cell attachment can be enhanced by coating of poly-dlysine on the metal while retaining the electrochemical activity of the metal electrode.The fraction of cells that were dead following overnight culture were similar among the tested material. In summary, my results suggest that electrodes fabricated from poly-dlysine coated DLC insulated with Teflon will selectively promote attachment of cells to measurement electrodes. 